\title{
A novel dimeric thymosin beta 4 with enhanced activities accelerates the rate of wound healing
}

This article was published in the following Dove Press journal:

Drug Design, Development and Therapy

30 September 2013

Number of times this article has been viewed

\author{
Tian-Jiao $\mathrm{Xu}^{1,2, *}$ \\ Qi Wangl,* \\ Xiao-Wen $\mathrm{Ma}^{\mathrm{I}}$ \\ Zhen Zhang ${ }^{3}$ \\ Wei Zhang' \\ Xiao-Chang Xue' \\ Cun Zhang' \\ Qiang Hao' \\ Wei-Na Li' \\ Ying-Qi Zhang' \\ Meng $\mathrm{Li}^{\prime}$
}

'State Key Laboratory of Cancer Biology, Biotechnology Center,

School of Pharmacy, Fourth Military

Medical University, Xi'an, People's

Republic of China; ${ }^{2}$ The Institute of

Medicine, Qiqihar Medical University,

Qiqihar, People's Republic of China;

${ }^{3}$ Department of Biochemistry and

Molecular Biology, University of

Kansas Medical Center, Kansas City,

KS, USA

*These authors contributed equally to this work

Correspondence: Ying-Qi Zhang

School of Pharmacy, Fourth Military

Medical University, 169 Changle West

Road, Xi'an, Shaanxi

710032, People's Republic of China

Tel +86 2984774773

Fax +86298324 72। 3

Email zhangyqh@fmmu.edu.cn

Correspondence: Meng Li

School of Pharmacy, Fourth Military

Medical University, 169 Changle West

Road, Xi'an, Shaanxi

710032, People's Republic of China

Tel +862984774772

Fax +86 2983247213

Email lemon78II06@hotmail.com
Objective: Thymosin beta 4 (T $\beta 4)$ is a peptide with 43 amino acids that is critical for repair and remodeling tissues on the skin, eye, heart, and neural system following injury. To fully realize its utility as a treatment for disease caused by injury, the authors constructed a costeffective novel T $\beta 4$ dimer and demonstrated that it was better able to accelerate tissue repair than native $\mathrm{T} \beta 4$.

Methods: A prokaryotic vector harboring two complete $\mathrm{T} \beta 4$ genes with a short linker was constructed and expressed in Escherichia coli. A pilot-scale fermentation (10 L) was performed to produce engineered bacteria and the $\mathrm{T} \beta 4$ dimer was purified by one-step hydrophobic interaction chromatography. The activities of the T $\beta 4$ dimer to promote endothelial cell proliferation, migration, and sprouting were assessed by tetramethylbenzidine (methylthiazol tetrazolium), trans-well, scratch, and tube formation assays. The ability to accelerate dermal healing was assessed on rats.

Results: After fermentation, the T $\beta 4$ dimer accounted for about $30 \%$ of all the bacteria proteins. The purity of the T $\beta 4$ dimer reached $98 \%$ after hydrophobic interaction chromatography purification. An average of $562.4 \mathrm{mg} / \mathrm{L} \mathrm{T} \beta 4$ dimer was acquired using a $10 \mathrm{~L}$ fermenter. In each assay, the dimeric T $\beta 4$ exhibited enhanced activities compared with native T $\beta 4$. Notably, the ability of the dimeric T $\beta 4$ to promote cell migration was almost two times higher than that of $\mathrm{T} \beta 4$. The rate of dermal healing in the dimeric $\mathrm{T} \beta 4$-treated rats was approximately 1 day faster than with native $\mathrm{T} \beta 4$-treated rats.

Conclusion: The dimeric T $\beta 4$ exhibited enhanced activity on wound healing than native $\mathrm{T} \beta 4$, and the purification process was simple and cost-effective. This data could be of significant benefit for the high pain and morbidity associated with chronic wounds disease. A better strategy to develop T $\beta 4$ as a treatment for other diseases caused by injuries such as heart attack, neurotrophic keratitis, and multiple sclerosis was also described.

Keywords: thymosin beta 4, dimer, wound healing, tissue repair, peptide, genetic engineering

\section{Introduction}

Thymosin beta 4 (T $\beta 4$ ) is a peptide with 43 amino acids and is the main component of fraction 5 of beta thymosin. ${ }^{1}$ It is present in all cells except red blood cells and in all body fluid. ${ }^{2,3} \mathrm{~T} \beta 4$ has been found to have considerable and broad biological activities, including promoting the migration of endothelial cells, ${ }^{4}$ accelerating angiogenesis, ${ }^{5,6}$ downregulating inflammatory responses, ${ }^{7,8}$ and inhibiting apoptosis and oxidative damage. ${ }^{9,10} \mathrm{~T} \beta 4$ also can organize the distribution of collagen by reducing the presence of myofibroblasts in the wound area. ${ }^{11}$ Angiogenesis is deemed as the most important mechanism for T $\beta 4$-induced cutaneous wound healing and cardioprotection. ${ }^{12,13}$ 
Angiogenesis is the physiological process through which new blood vessels form from pre-existing vessels. It is vital for tissue repair as cell survival and regeneration depends on a sufficient supply of nutrients and oxygen. In endothelial cells, proliferation, migration, and then sprouting to become a vessel lumen are well-characterized stages of angiogenesis. ${ }^{14}$

Two independent randomized, double-blind clinical trials proved that a $\mathrm{T} \beta 4$ topical gel accelerates dermal healing approximately 1 month faster than a placebo in pressure ulcers (full thickness) and venous stasis ulcers patients. ${ }^{15,16}$ Some Stage IV wounds that had been present as long as 2 years only healed completely in the T $\beta 4$ gel treatment group. ${ }^{17}$ RegeneRx Biopharmaceuticals, Inc. (Rockville, MD, USA) acquired an exclusive worldwide license for the use of $\mathrm{T} \beta 4$ in wound healing from the National Institutes of Health (Bethesda, MD, USA). The applications of T $\beta 4$ in the treatment of other diseases caused by injury such as myocardial infarction or reperfusion injury, ${ }^{12,18,19}$ corneal injury, ${ }^{20}$ and brain traumatic or ischemia injuries ${ }^{21,22}$ have also entered into clinical stage in recent years.

Currently, $\mathrm{T} \beta 4$ products used in clinical and preclinical studies are chemically synthesized. Industrial-scale peptide synthesis is a costly, time-consuming, and highly polluting process especially for long peptides like $\mathrm{T} \beta 4$. On the other hand, the genetic engineering production of intact $\mathrm{T} \beta 4$ failed in several reports, ${ }^{23,24}$ which was attributed to the susceptibility of small peptides to proteolytic degradation. ${ }^{25}$ Protein tag fusion strategies and excess amino acids to resist degradation have been used $\mathrm{d}^{23,24}$ to mitigate the susceptibility. However, the multiple purification steps and potential immunogenicity have not been cost-effective and satisfactory for therapeutic applications. Since the theoretical molecular weight (MW) of the T $\beta 4$ dimer is over 9,500.0 Da, which satisfies the recombinant technology, and evidence that the dimerization of some cytokines or hormones strongly increase their activities and lifespan, ${ }^{25-27}$ it was hypothesized that the fusing of two T $\beta 4$ molecules might confer an increase in its intrinsic activities and successful production using genetic engineering.

To prove this hypothesis, a prokaryotic vector harboring two entire T $\beta 4$ genes with a small linker was constructed and expressed in Escherichia coli in the present study. After a large-scale cultivation of the engineered bacteria, the T $\beta 4$ dimer (DT $\beta 4$ ) accounted for about $30 \%$ of all the proteins. The purity of DT $\beta 4$ reached $98 \%$ after a simple hydrophobic interaction chromatography (HIC) purification. An average of $562.4 \mathrm{mg} / \mathrm{L}$ DT $\beta 4$ was acquired using a $10 \mathrm{~L}$ fermenter. This dimer showed enhanced abilities to promote the proliferation, migration, and tube formation of the endothelial cells in vitro. Since the applications of T $\beta 4$ in wound healing is more mature than in other diseases, and chronic cutaneous wounds are associated with significant morbidity especially in elderly, diabetes, and disability patients, ${ }^{28}$ the activities of DT $\beta 4$ to promote wounding healing were assessed in rats. The DT $\beta 4$ exhibited stronger biological activity on wound healing than the native T $\beta 4$ monomer, which demonstrates the possibilities of clinical applications for the genetically engineered DT $\beta 4$. In the future, the authors hope to prove the potential uses of this molecule in the treatment of other diseases caused by injuries.

\section{Materials and methods Construction of DT $\beta 4$ expression vector}

Two entire complementary DNA sequences of T $\beta 4$ (UniProt: P62328) optimized with E. coli-preferred codons were synthesized by Bio Asia Diagnostics, Inc., (Shanghai, People's Republic of China) with a small DNA sequence linker (GGTTCT) between them, and were constructed into prokaryotic expression plasmid pET22b(+) (Promega Corporation, Fitchburg, WI, USA) by NdeI and SalI restriction enzymes. The resulting expression plasmid was designated pET22b-DT $\beta 4$ and verified by agarose electrophoresis and DNA sequencing.

\section{Expression of DT $\beta 4$ and large-scale cultivation of engineered bacteria}

The pET22b-DT $\beta 4$ plasmid was transformed into E. coli BL21 (DE3; Promega) using the calcium chloride method. Successfully transformed BL21 clones were used for recombinant DT $\beta 4$ expression. Large-scale cultivation was performed using a $10 \mathrm{~L}$ fermenter (CT5-2; B. Braun Biotech International $\mathrm{GmbH}$, Melsungen, Germany). Extended details are shown in Supplementary materials.

\section{Purification of DT $\beta 4$}

A $10 \%$ (weight/volume) bacteria suspension in $50 \mathrm{mmol} / \mathrm{L}$ tris(hydroxymethyl)aminomethane-hydrogen chloride with $100 \mathrm{mmol} / \mathrm{L}$ sodium chloride and $5 \mathrm{mmol} / \mathrm{L}$ ethylenediaminetetraacetic acid (buffer $\mathrm{A}, \mathrm{pH}$ 8.0) was prepared for the purification. The cells were lysed by sonification using an ultrasonic processor (JY92-2D; Xinzhi Biotech Inc., Ningbo, People's Republic of China). The cell debris was removed by centrifugation $(12,000 \mathrm{rpm}$, 20 minutes, $4^{\circ} \mathrm{C}$ ). Ammonium sulfate precipitation and HIC were used to purify DT $\beta 4$. The details are shown in Supplementary materials. 


\section{Basic quality determinations of DT $\beta 4$}

Protein quantitation of the purified sample was determined by the standard Bradford method. The purity was determined by sodium dodecyl sulfate polyacrylamide gel electrophoresis (SDS-PAGE) and high-performance liquid chromatography (Alliance ${ }^{\circledR}$ HPLC; Waters Corporation, Milford, MA, USA). The actual MW was determined by matrix-assisted laser desorption/ionization time-of-flight mass spectroscopy (Applied Biosystems ${ }^{\circledR} 4800$ Plus; Life Technologies, Carlsbad, CA, USA). Simultaneously, $\mathrm{N}$-terminal sequencing was finished by ProtTech, Inc., (Phoenixville, PA, USA). The structure of DT $\beta 4$ was confirmed by Western blot using the $\mathrm{T} \beta 4$ monoclonal antibody (Abcam plc, Cambridge, UK).

\section{Bioactivities of DT $\beta 4$ in vitro and in vivo \\ Cells and animals}

Human umbilical vein endothelial cells (HUVEC) were maintained in Gibco ${ }^{\circledR}$ RPMI 1640 (Life Technologies) supplemented with Gibco ${ }^{\circledR} 10 \%$ fetal bovine serum (Life Technologies), $100 \mathrm{U} / \mathrm{mL}$ penicillin, and $100 \mu \mathrm{g} / \mathrm{mL}$ streptomycin (Thermo Fisher Scientific, Waltham, MA, USA). All cells were incubated at $37^{\circ} \mathrm{C}$ in $5 \%$ carbon dioxide. The cells used for all studies were taken from passage two. Sprague Dawley rats weighing about $220 \mathrm{~g}$ were purchased from Experimental Animal Center of Fourth Military Medical University (Xian, People's Republic of China). All protocols were approved by the Committee for the Care and Use of Experimental Animals of the University.

\section{The effect of DT $\beta 4$ on the proliferation of HUVEC} HUVEC were grown to $70 \%$ confluence in a $96-$ well plate $\left(3,000\right.$ cells/well initially) and incubated at $37^{\circ} \mathrm{C}$ with DT $\beta 4$, $\mathrm{T} \beta 4$, or phosphate-buffered saline (PBS) in triplicate. The $\mathrm{T} \beta 4$ monomer was synthesized in the authors' lab and used as the control. The final concentrations of $0.5,1,2,4$, and $8 \mu \mathrm{g} / \mathrm{mL}$ were applied. Forty-eight hours later, the wells were developed with tetramethylbenzidine (methylthiazol tetrazolium) (Sigma-Aldrich, St Louis, MO, USA), and the absorbance $(490 \mathrm{~nm})$ was determined by a microplate reader (ELx800; BioTek Instruments, Inc., Winooski, VT, USA).

\section{The effect of DT $\beta 4$ on the migration of HUVEC}

The effect of DT $\beta 4$ to promote the migration of HUVEC was tested by trans-well assay and scratch assay. Two concentrations were applied $(1 \mu \mathrm{g} / \mathrm{mL}$ and $10 \mu \mathrm{g} / \mathrm{mL})$. Extended details are shown in Supplementary materials.

\section{The effect of DT $\beta 4$ on angiogenesis}

The effect of DT $\beta 4$ to stimulate angiogenesis was evaluated by endothelial tube formation assay. Two concentrations were applied $(1 \mu \mathrm{g} / \mathrm{mL}$ and $10 \mu \mathrm{g} / \mathrm{mL})$. Extended details are shown in Supplementary materials.

\section{The effects of DT $\beta 4$ on the wound healing in rats} DT $\beta 4$ hydrogel was prepared at three concentrations: $0.5 \mathrm{mg} / \mathrm{mL}, 0.25 \mathrm{mg} / \mathrm{mL}$, and $0.125 \mathrm{mg} / \mathrm{mL}$. T $\beta 4$ hydrogel was prepared at $0.25 \mathrm{mg} / \mathrm{mL}$ and used as the control. The methods for wound repair evaluation in rats are described in Supplementary materials.

\section{Statistics}

All results are presented as mean \pm standard deviation. For all of the biological activity validations in vitro and in vivo, a comparison of the difference in the mean findings between two groups was performed using a two-sided Student's $t$-test with unequal variance. Statistical significance was assessed at the 0.05 level.

\section{Results \\ Cloning and expression of DT $\beta 4$}

The DNA sequence encoding two identical $\mathrm{T} \beta 4$ with a short linker was synthesized and cloned into expression vector pET22b(+). The recombinant plasmid pET22b-DT $\beta 4$ was confirmed by NdeI/SalI digestion and sequencing. The results show a $267 \mathrm{bp}$ fragment with correct sequence as expected (Figure 1A). Five colonies obtained after the transformation of BL21 with pET22b-DT $\beta 4$ were randomly picked to test the protein expression on a small scale. After isopropyl $\beta$-D1-thiogalactopyranoside induction, a new protein appeared in each culture pellet (Figure 1B) and accounted for over 15\% of all the bacteria proteins. The clone with the highest expression level of DT $\beta 4$ was selected for large-scale cultivation.

\section{Large-scale cultivation of BL2I/pET22b-DT $\beta 4$}

In a $10 \mathrm{~L}$ fermenter, recombinant BL21 entered into log phase 6 hours after inoculation, and isopropyl $\beta$-D-1thiogalactopyranoside induction was initiated at this time (Figure 1C). Optical density at $600 \mathrm{~nm}$ was about 6 at induction initiation. The cultivation was stopped when the growth entered into a stationary phase which was about 5 hours after induction. The expression of DT $\beta 4$ at this stage accounted for about $30 \%$ of all the bacteria proteins (Figure 1D) and optical density at $600 \mathrm{~nm}$ was $>25$. The fermentation was repeated three times, an average of $185.5 \mathrm{~g}$ cell paste was harvested each time. The parameters each time were similar, 
A

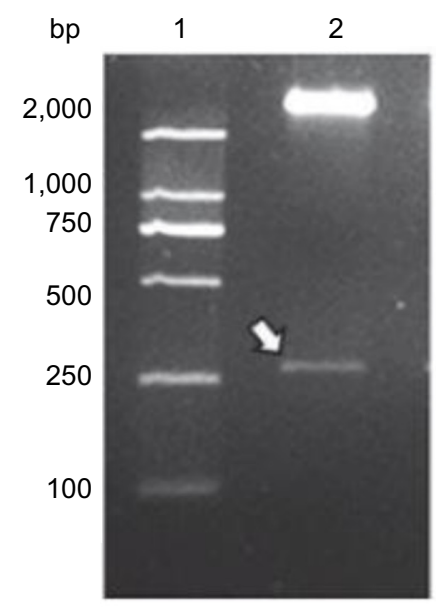

B

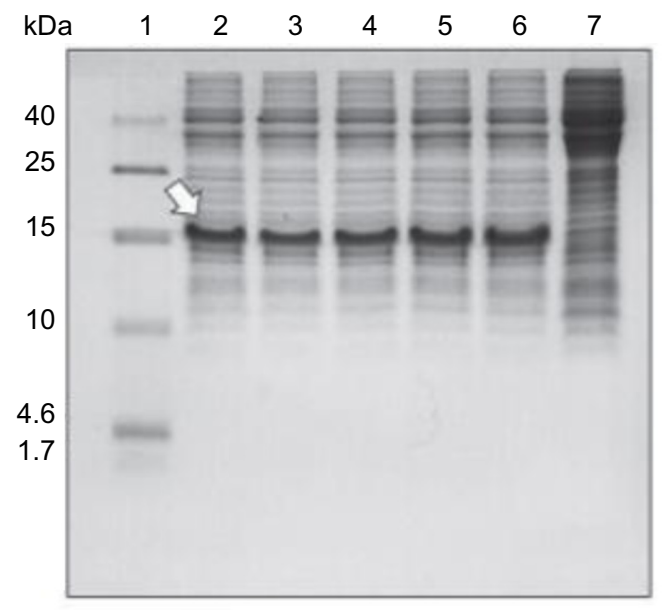

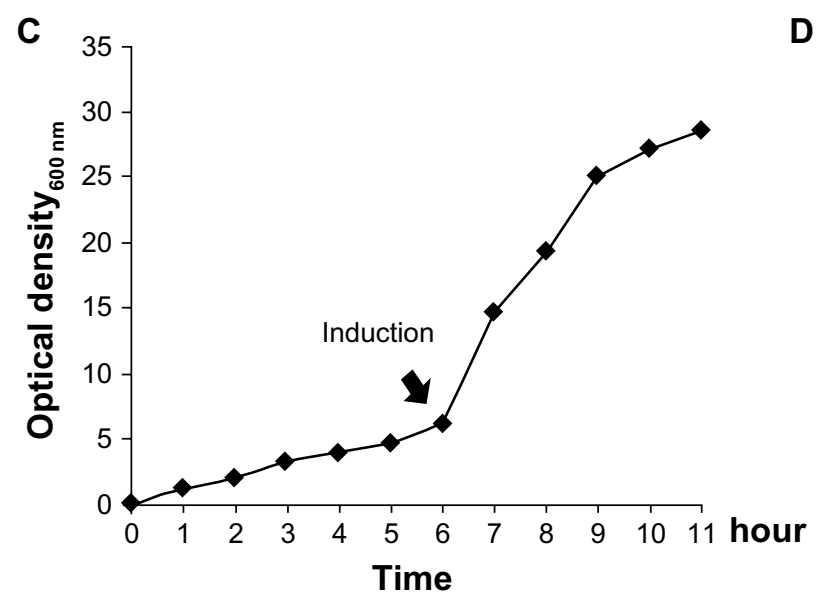

D $\quad \begin{array}{lllllll}1 & 2 & 3 & 4 & 5 & 6\end{array}$

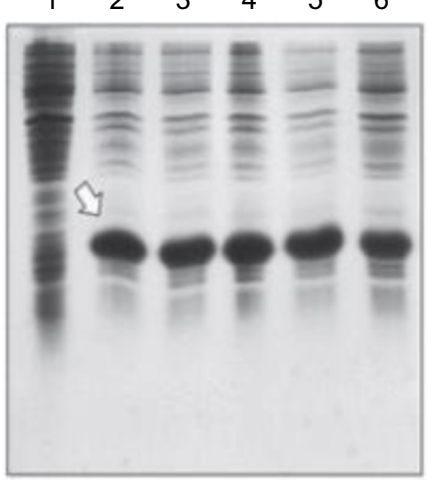

Figure I Cloning, expression, and large-scale cultivation of dimeric thymosin beta 4 (DT $\beta 4$ ) engineered bacteria. (A) Two entire complementary DNA sequences of thymosin beta 4 (TR4) were constructed into a prokaryotic expression plasmid with a small DNA linker (GGTTCT). The results show a 267 bp fragment with correct sequence as expected (arrow). (B) Five colonies obtained after the transformation of Escherichia coli were randomly picked to test the protein expression on a small scale with sodium dodecyl sulfate polyacrylamide gel electrophoresis. After isopropyl $\beta$-D-I-thiogalactopyranoside (IPTG) induction, a new protein (arrow) appeared in each culture pellet and accounted for over I5\% of all the bacteria proteins (I: molecular ladder; 2-6: protein expression of picked five clones; 7: protein expression without IPTG induction). (C) Bacterial growth curve of BL2I/DT $\beta 4$ in a $10 \mathrm{~L}$ fermenter (the arrow indicates the induction time). (D) DT 34 expression (arrow) during fermentation (I: DT $\beta 4$ expression without IPTG induction; 2-6: DT 34 expression every hour after IPTG induction).

Abbreviation: DNA, deoxyribonucleic acid.

indicating that the condition of fermentation was appropriate for recombinant BL21 growth and DT $\beta 4$ expression.

\section{Purification and identification of DT $\beta 4$}

As DT $\beta 4$ has a good solubility, most of DT $\beta 4$ was in the buffered supernatant after sonification. Fifty percent ammonium sulfate precipitated most of the bacteria protein in the supernatant, which was a crude purification step. The resulting supernatant was further separated by HIC, and DT $\beta 4$ was detected in the first elution fraction (Figure $2 \mathrm{~A}$ and $\mathrm{B}$ ). The DT $\beta 4$ purity in this fraction was over $98 \%$ determined by high-performance liquid chromatography (Figure 2C). The actual MW of purified DT $\beta 4$ detected by mass spectroscopy was 9,961.0 Da, which was consistent with the theoretical MW despite the apparent MW of DT $\beta 4$ being about $15 \mathrm{kDa}$ in SDS-
PAGE (Figure 3A). The seven amino acids at the N-terminal of DT $\beta 4$ were methionine-serine-aspartic acid-lysine-prolineaspartic acid-methionine (MSDKPDM) as expected. DT $\beta 4$ was recognized by $\mathrm{T} \beta 4$ monoclonal antibody as shown by Western blot (Figure 3B). The whole purification procedure and identifications were repeated three times. Table 1 shows the yields of three batches of fermentation and purification. On average, $562.4 \mathrm{mg}$ of DT $\beta 4$ could be obtained from $1 \mathrm{~L}$ of cultivation. The results of each replication were consistent, indicating that the purification procedure of DT $\beta 4$ was stable and reliable.

\section{Activities of DT $\beta 4$ and T $\beta 4$ on HUVEC}

DT $\beta 4$ as well as T $\beta 4$ promoted the proliferation of HUVEC in a dose-dependent manner in the detected concentration 


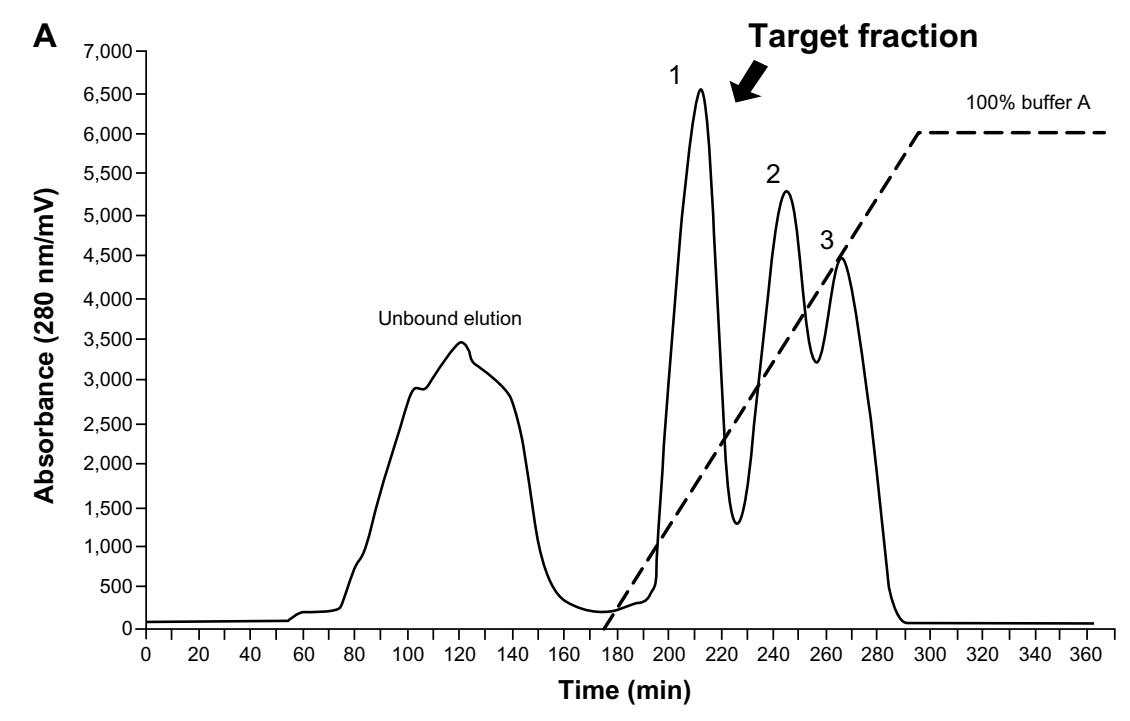

\section{B}
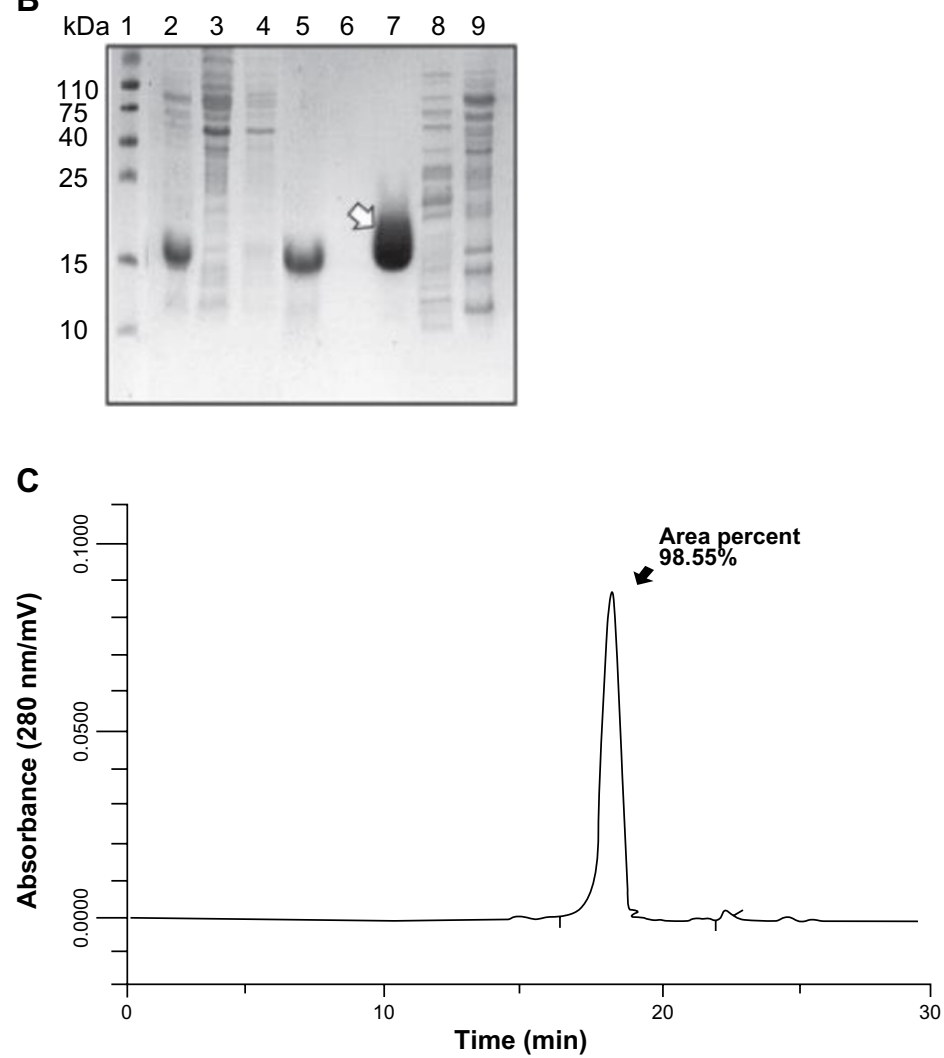

Figure 2 Chromatogram of dimeric thymosin beta 4 (DTß4) purification and high-performance liquid chromatography identification. (A) Chromatogram of hydrophobic interaction chromatography purification. DT $\beta 4$ was detected in the first elution fraction. (B) Sodium dodecyl sulfate polyacrylamide gel electrophoresis identification of each step during purification (I: molecular ladder; 2: DT $\beta 4$ expression after isopropyl $\beta$-D-I-thiogalactopyranoside induction; 3: without isopropyl $\beta$-D-I-thiogalactopyranoside; 4: the precipitation of $50 \%$ ammonium sulfate; 5: the supernatant of $50 \%$ ammonium sulfate [loading sample of hydrophobic interaction chromatography]; 6 : unbounded elution; 7-9: elution fractions). The arrow indicates purified DT $\beta 4$ in the first elution. (C) High-performance liquid chromatography identification of the first elution.

range (Figure 4). At each concentration, DT $\beta 4$ exhibited significantly more promotion on HUVEC than T $\beta 4$ $(P<0.01)$. Compared with PBS, DT $\beta 4$ showed promotion at $0.5 \mu \mathrm{g} / \mathrm{mL}$, whereas $\mathrm{T} \beta 4$ showed similar effects at $2 \mu \mathrm{g} / \mathrm{mL}$.
In the trans-well assay, DT $\beta 4$ exhibited more chemotactic effects on HUVEC (Figure 5). At $1 \mu \mathrm{g} / \mathrm{mL}$, an average of $38.5 \pm 1.5$ cells migrated to the filter in response to DT $\beta 4$ compared with $21.3 \pm 1.5$ for $\mathrm{T} \beta 4(P<0.01)$. At $10 \mu \mathrm{g} / \mathrm{mL}$, $59.8 \pm 2.5$ cells migrated to DT $\beta 4$ compared with $29.6 \pm 1.8$ 


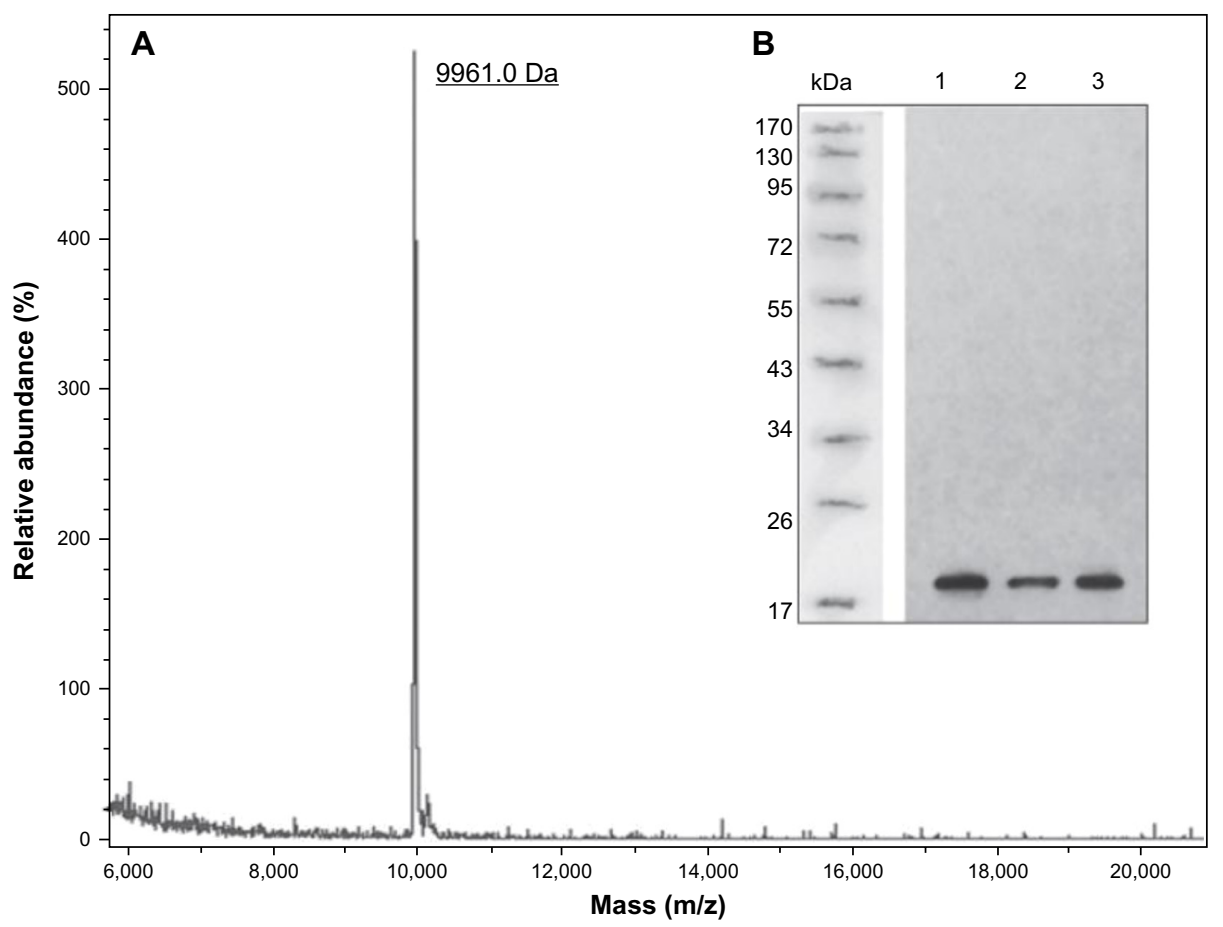

Figure 3 The molecular weight and structure validations of dimeric thymosin beta 4 (DT $\beta 4$ ) with matrix-assisted laser desorption/ionization time-of-flight mass spectroscopy and Western blot. (A) The actual molecular weight of purified DT $\beta 4$ detected by mass spectroscopy was $9,961.0$ Da, which was consistent with its theoretical molecular weight. (B) DT $\beta 4$ was recognized by thymosin beta 4 (TR4) monoclonal antibody (I-3: samples of three batches).

for T $\beta 4(P<0.01)$. The number of cells on the PBS treatment filter was $5.2 \pm 1.1$.

In the scratch assay, DT $\beta 4$ exhibited more promotions on the scratch closure than T $\beta 4$. Figure 6 shows the representative images of scratched HUVEC after 12-hour treatments with DT $\beta 4$ or T $\beta 4$. The average distance that HUVEC moved from the edge of the scratch toward the center with $1 \mu \mathrm{g} / \mathrm{mL}$ DT $\beta 4$ treatment was $45.32 \pm 8.8 \mu \mathrm{m}$ compared with $22.45 \pm 4.2 \mu \mathrm{m}$ for $\mathrm{T} \beta 4(P<0.01)$. After $10 \mu \mathrm{g} / \mathrm{mL}$ DT $\beta 4$ treatment, HUVEC moved $80.2 \pm 9.8$ compared with $56.5 \pm 4.8$ for T $\beta 4(P<0.01)$. The distance HUVEC moved without any treatment was $21.38 \pm 3.2 \mu \mathrm{m}$, which is a significantly smaller distance than that observed with $1 \mu \mathrm{g} / \mathrm{mL}$ DT $\beta 4$ but not $1 \mu \mathrm{g} / \mathrm{mL}$ T $\beta 4$.

In the tube formation assay, the stimulation of DT $\beta 4$ on capillary-like structures caused a stronger formation of
HUVEC than with T $\beta 4$ (Figure 7). At $1 \mu \mathrm{g} / \mathrm{mL}$, an average of $52.67 \pm 3.2$ capillary-like structures were observed in DT $\beta 4$ wells compared with $34.33 \pm 2.3$ for T $\beta 4(P<0.01)$. At $10 \mu \mathrm{g} / \mathrm{mL}$, the numbers increased to $86.34 \pm 6.7$ and $68.67 \pm 2.4$, respectively $(P<0.01)$. The average number of structures observed in the PBS control was 21.67 \pm 1.2 , which is significantly lower than that of DT $\beta 4$ and T $\beta 4(P<0.01)$.

All results on HUVEC indicate the multiple functions of DT $\beta 4$ and T $\beta 4$. The ability of DT $\beta 4$ to promote endothelial cells growth, migration, and angiogenesis was stronger than $\mathrm{T} \beta 4$.

\section{Promotions of wound repair in rats}

During the study, no abnormalities were observed in the general condition and behavior of rats in all treatment cohorts, including asitia, nausea, diarrhea, cough, or weight loss,

Table I The results of three batches of fermentation and purification of recombinant dimeric thymosin beta 4

\begin{tabular}{|c|c|c|c|c|c|c|c|}
\hline \multirow[t]{2}{*}{ Batch } & \multicolumn{2}{|l|}{ OD $_{600 \mathrm{~nm}}$} & \multirow{2}{*}{$\begin{array}{l}\text { Yield of bacteria } \\
\text { (g/L) }\end{array}$} & \multirow{2}{*}{$\begin{array}{l}\text { Yield of DT } \beta 4 \\
\text { (mg/L) }\end{array}$} & \multirow{2}{*}{$\begin{array}{l}\text { Purity } \\
\text { (\%) }\end{array}$} & \multicolumn{2}{|c|}{ Average } \\
\hline & Induction & Harvest & & & & $\begin{array}{l}\text { Yield } \\
\text { (mg/L) }\end{array}$ & $\begin{array}{l}\text { Purity } \\
\text { (\%) }\end{array}$ \\
\hline 1 & 6.20 & 25.1 & 32.56 & 570.35 & 98.46 & & \\
\hline 2 & 6.14 & 27.9 & 34.44 & 552.75 & 98.55 & 562.4 & 98.38 \\
\hline 3 & 6.21 & 29.1 & 33.88 & 564.35 & 98.13 & & \\
\hline
\end{tabular}

Abbreviations: DT $\beta 4$, dimeric thymosin beta $4 ; \mathrm{OD}_{600 \mathrm{~nm}}$, optical density at $600 \mathrm{~nm}$. 


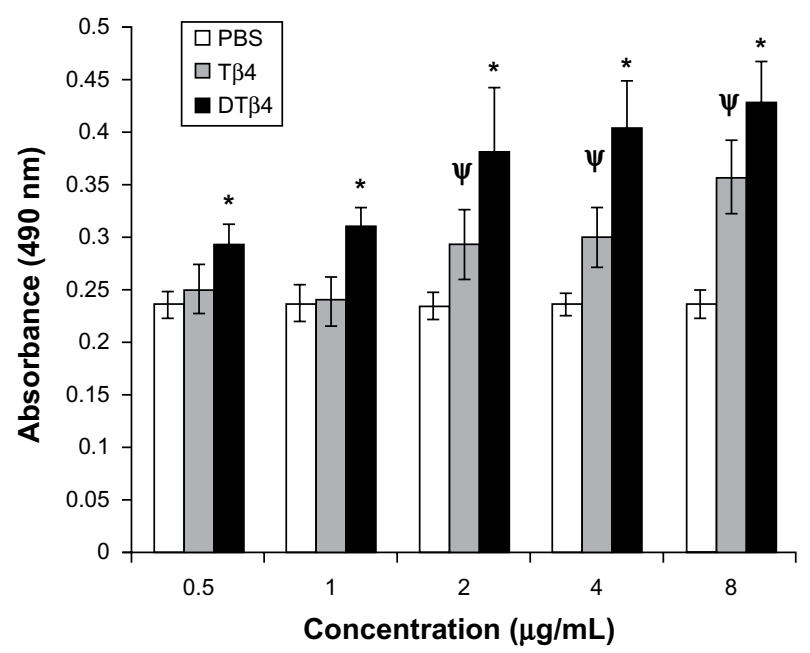

Figure 4 The proliferation of human umbilical vein endothelial cells under different concentrations of dimeric thymosin beta 4 (DT $\beta 4)$, thymosin beta 4 (T $\beta 4)$, and phosphate-buffered saline (PBS). DT $\beta 4$ as well as T $\beta 4$ promoted the proliferation of human umbilical vein endothelial cells in a dose-dependent manner in the 0-10 $\mu \mathrm{g} / \mathrm{mL}$ concentration range. At each concentration, DT $\beta 4$ exhibited significant promotion compared with T $\beta 4$. Compared with PBS, DT $\beta 4$ showed a promotion effect at $0.5 \mu \mathrm{g} / \mathrm{mL}$, whereas T $\beta 4$ showed a similar effect at $2 \mu \mathrm{g} / \mathrm{mL}$. Notes: $* P<0.0$ I versus T $\beta 4 ;, \psi P<0.0$ I versus PBS. and no symptoms of allergic response such as hydroposia or localized rash occurred in animals receiving DT $\beta 4$ or T $\beta 4$. The final autopsy did not show any pathological changes in various organs.

Wound repair evaluation proved either DT $\beta 4$ or $\mathrm{T} \beta 4$ increased wound healing, and a $50 \%$ wound closure was observed as early as day three after wound creation in the mid-dose DT $\beta 4(0.25 \mathrm{mg} / \mathrm{mL})$ treatment cohort. The rates of $50 \%$ healing in mid-dose DT $\beta 4$-treated rats were approximately 3 days faster than the plain hydrogel and 1 day faster than T $\beta 4$-treated rats. The healing of the plain hydrogel and T $\beta 4$ eventually caught up with the mid-dose DT $\beta 4$ treatment at days nine and seven, respectively (Figure 8A). Table 2 shows the wound closure percentages of each cohort during the study. The final histological sections of each cohort show good re-epithelialization and angiogenesis in subcutaneous tissue (Figures 8B-D). Compared with plain hydrogel, both DT $\beta 4$ and T $\beta 4$ resulted in more capillary growth. All of these data demonstrate that DT $\beta 4$ is most
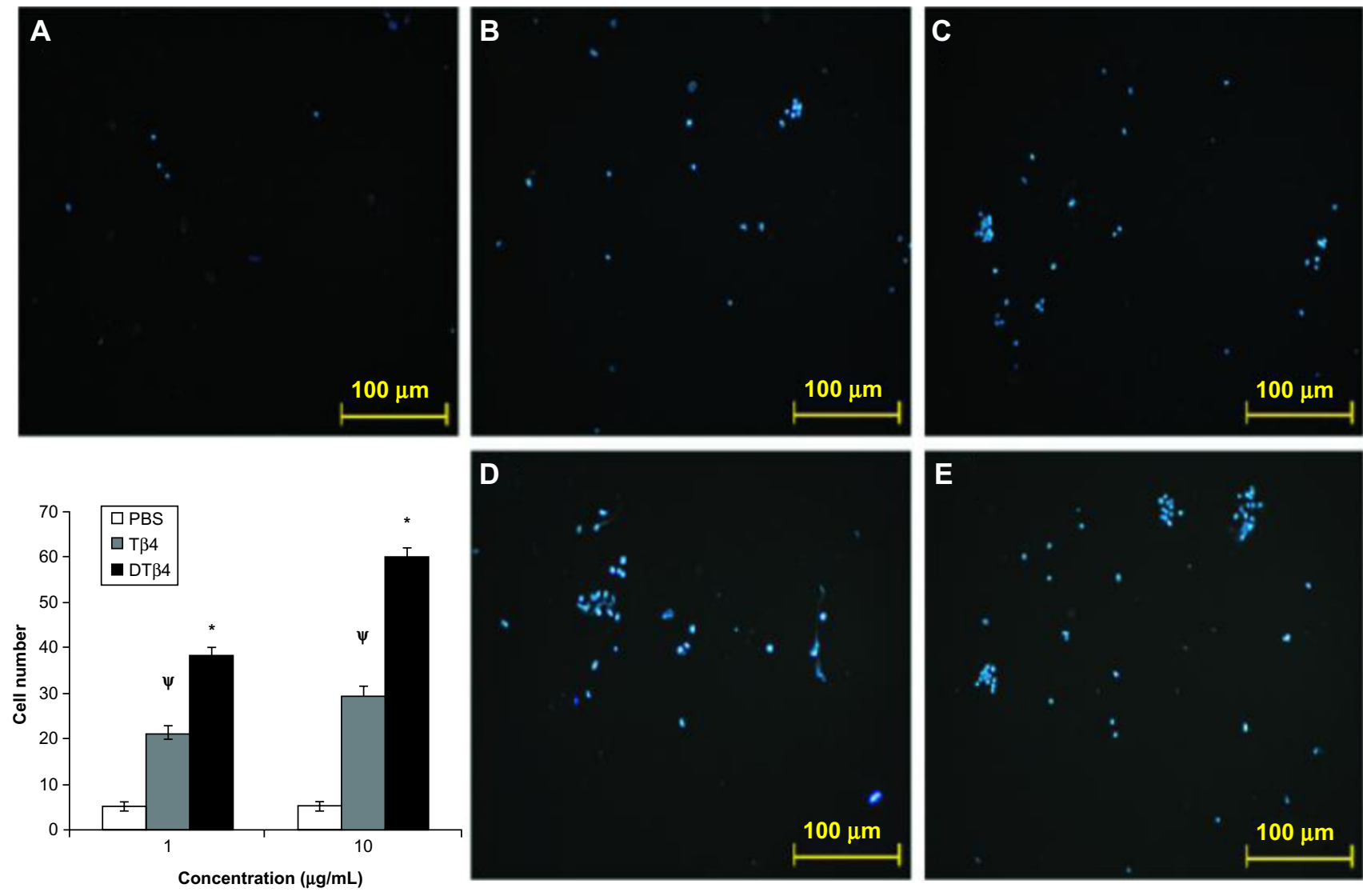

Figure 5 Dimeric thymosin beta 4 (DT $\beta 4$ ) exhibited more chemotactic effects on human umbilical vein endothelial cells than thymosin beta 4 (T $\beta 4$ ) and phosphate-buffered saline (PBS) in the trans-well assay. At I $\mu \mathrm{g} / \mathrm{mL}$, an average of $38.5 \pm 1.5$ cells migrated onto the filter in response to DT $\beta 4$ compared with $21.3 \pm 1.5$ in response to T $\beta 4$. At $10 \mu \mathrm{g} / \mathrm{mL}, 59.8 \pm 2.5$ cells migrated in response to DT $\beta 4$ compared with $29.6 \pm 1.8$ in response to T $\beta 4$. The number of cells on the PBS treatment filter was $5.2 \pm 1.1$. (A)

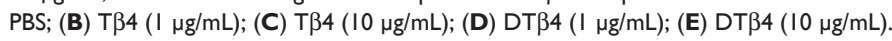

Notes: ${ }^{*} P<0.0$ I versus $T \beta 4 ;{ }^{*} P<0.01$ versus $P B S$. 

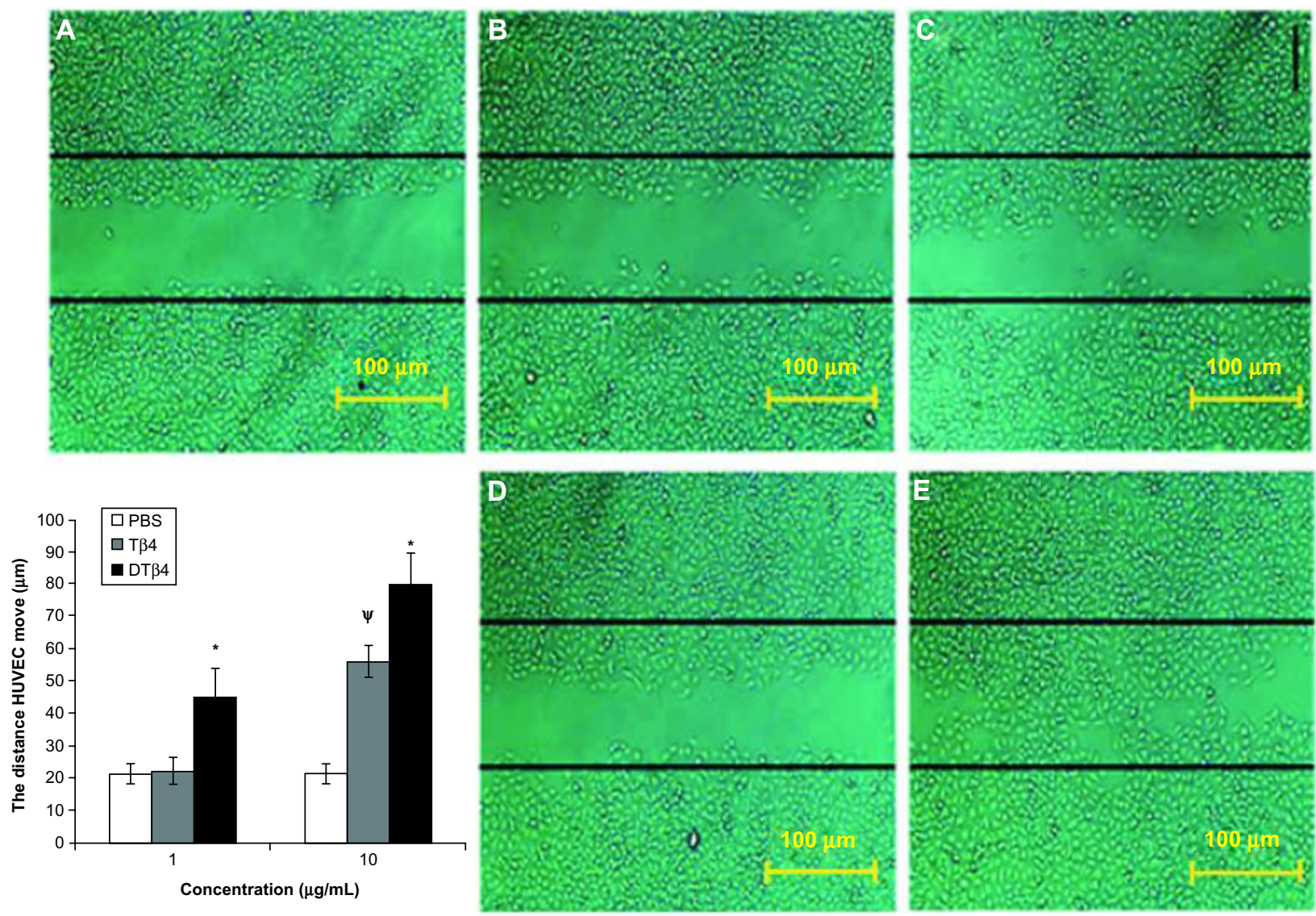

Figure 6 Dimeric thymosin beta 4 (DT $\beta 4$ ) exhibited more promotions than thymosin beta 4 (T $\beta 4$ ) and phosphate-buffered saline (PBS) in the scratch assay. After I2 hours of treatment, the average distance that human umbilical vein endothelial cells moved from the edge of the scratch towards the center with I $\mu \mathrm{g} / \mathrm{mL} \mathrm{DT} \beta 4 \mathrm{treatment}$ was $45.32 \pm 8.8 \mu \mathrm{m}$ compared with $22.45 \pm 4.2 \mu \mathrm{m}$ for T $\beta 4$. After $10 \mu \mathrm{g} / \mathrm{mL}$ DT $\beta 4$ treatment, the human umbilical vein endothelial cells moved $80.2 \pm 9.8 \mu \mathrm{m}$ compared with $56.5 \pm 4.8 \mu \mathrm{m}$ for T $\beta 4$. The human umbilical vein endothelial cells without any treatment moved $21.38 \pm 3.2 \mu \mathrm{m}$, which was a significantly smaller distance than that of I $\mu \mathrm{g} /$

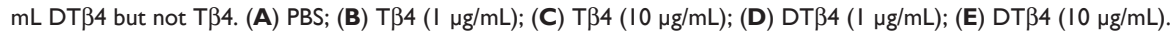

Notes: $* P<0.01$ versus $T \beta 4 ; \psi P<0.01$ versus PBS.

Abbreviation: HUVEC, human umbilical vein endothelial cells.

effective in the mid-dose range and accelerates wound healing, which resembles previous conclusions about $\mathrm{T} \beta 4 .{ }^{17} \mathrm{At}$ the same time, these data also suggest DT $\beta 4$ is more effective than T $\beta 4$ in wound repair.

\section{Discussion}

As the genetic engineering production of intact $\mathrm{T} \beta 4$ failed, and protein tag fusion strategies and excess amino acids to resist degradation ${ }^{23,24}$ were complicated in the purification process and have potential immunogenicity, better methods for recombination production of $\mathrm{T} \beta 4$ are required. The recombined DT $\beta 4$ does not introduce a foreign sequence, exhibits a more enhanced activity than the T $\beta 4$ monomer, and has a cheap, simple, and time-saving production process. Therefore, recombinant DT $\beta 4$ is a superior means to produce $\mathrm{T} \beta 4$ for medicine applications.

The simplicity of the purification process of DT $\beta 4$ is attributed to the hydrophilicity and good solubility of T $\beta 4$. Ammonium sulfate precipitation and HIC produced a $>98 \%$ purity of DT $\beta 4$. There were no dialysis and buffer changes between the purification steps. After triplicate pilot-scale fermentation $(10 \mathrm{~L})$ and purification steps, an average yield of $560 \mathrm{mg} / \mathrm{L}$ was obtained. The data of DT $\beta 4$ fermentation and purification indicate that the recombinant DT $\beta 4$ is a cost-effective means to enable commercial enterprises to produce it on a large scale.

In this study, the apparent MW of DT $\beta 4$ in SDS-PAGE was not consistent with its theoretical value. This deviation was reproducible. As the MW determined by mass spectroscopy was correct and the monoclonal antibody could recognize DT $\beta 4$, it is speculated that this is due to the properties of the protein itself. In fact, the MW deviations of native T $\beta 4$ and DT $\beta 4$ were found in SDS-PAGE. T $\beta 4$ is a highly hydrophilic protein, but most amino acids are polar proteins, which may result in a less negative charge after SDS treatment. In this situation, mobility would decrease. Further research is required to determine if there are other reasons for this discrepancy, for example, structure change. 

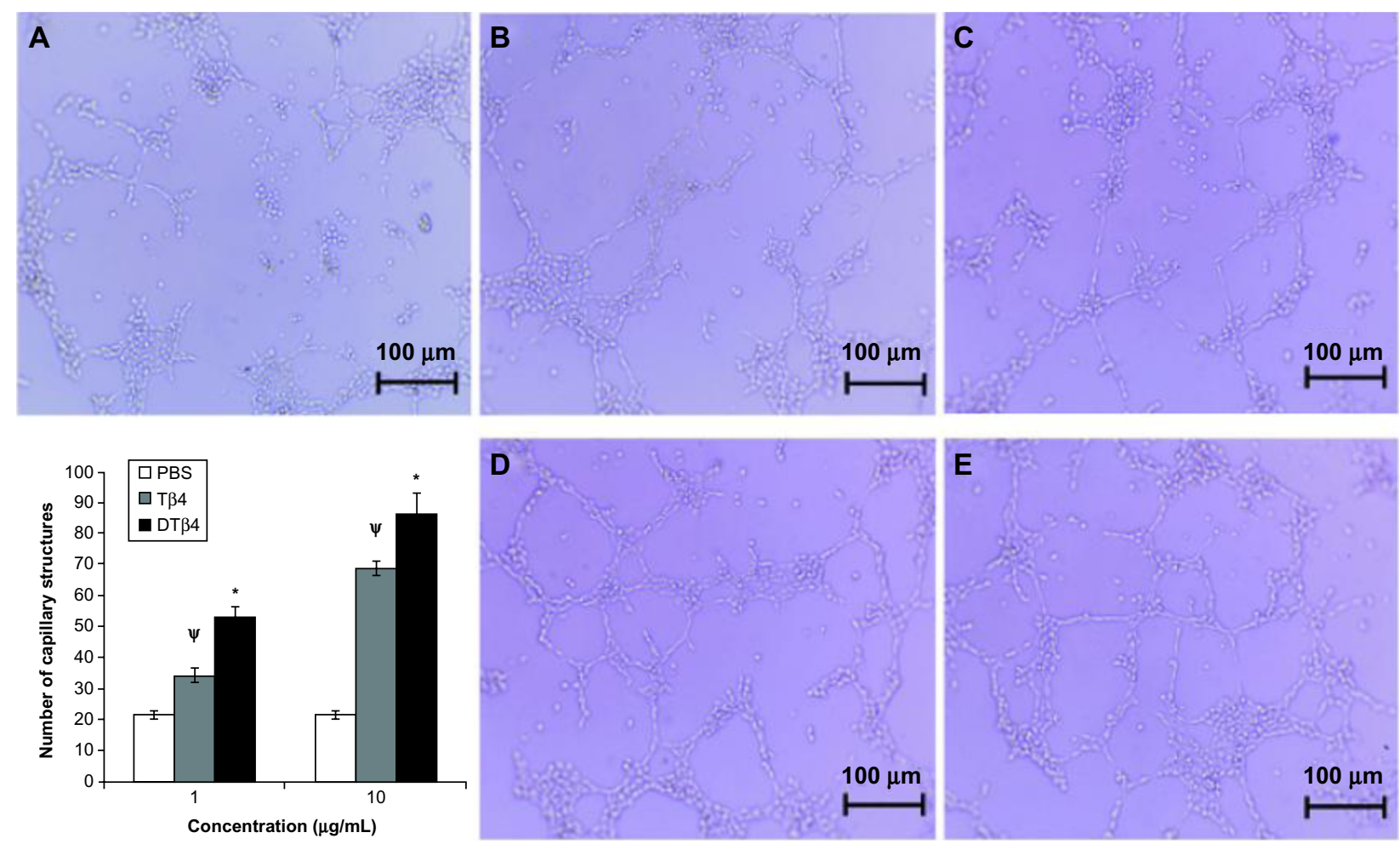

Figure 7 The stimulation of dimeric thymosin beta 4 (DT $\beta 4)$ on the capillary-like structure formation of human umbilical vein endothelial cells was stronger than thymosin beta 4 (Tß4) and phosphate-buffered saline (PBS). At I $\mu \mathrm{g} / \mathrm{mL}$, an average of $52.67 \pm 3.2$ capillary-like structures was observed in DT $\beta 4$ wells compared with $34.33 \pm 2.3$ for $\mathrm{T} \beta 4$. At $10 \mu \mathrm{g} / \mathrm{mL}$, the average increased to $86.34 \pm 6.7$ and $68.67 \pm 2.4$, respectively. The average number of structures observed in PBS wells was $21.67 \pm 1.2$, which was

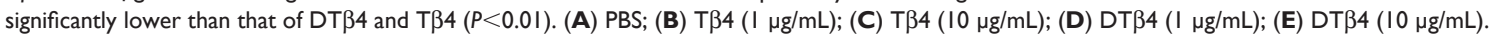

Notes: $* P<0.01$ versus $T \beta 4 ;{ }^{*} P<0.01$ versus PBS.

Understanding why a dimeric protein has enhanced activity is always based on the study of the original monomer. For example, the reason recombinant erythropoietin (Epo) dimer has enhanced erythropoietic activity is speculated to be Epo-Epo fusion bridges, where two adjacent Epo receptors trigger the active state of Epo receptor. ${ }^{26,29,30}$ However, the exact mechanism of T $\beta 4$ is still ambiguous, especially when the multiple activities and several active sites located on the molecule are considered. ${ }^{31}$ The widely accepted theory is that $\mathrm{T} \beta 4$ binds to/releases the G-actin monomer with its actinbinding site (amino acids 17-22) and coordinates F-actin depolymerization/polymerization to promote cell motility. ${ }^{32}$ Other studies insist $\mathrm{T} \beta 4$ functions through receptors such as the adenosine receptors. ${ }^{33} \mathrm{~T} \beta 4$ action is also believed to activate protein kinase $\mathrm{B}$ in an integrin-linked kinase-dependent manner. ${ }^{18}$ Various results on the mechanism of $\mathrm{T} \beta 4$ actions suggest it exerts functions via different mechanisms in different situations. In such a case, it is hard to speculate the exact reasons for the enhanced activity of DT $\beta 4$. Even though the mechanism is not clear, it is a fact that the dimerization of some cytokines or hormones increased their activities and lifespan. Thus, the construction of dimers or multimers represents a new method for the genetic engineering production of many small bioactive peptides.

In pre-experiments, it was found that T $\beta 4$ and DT $\beta 4$ exhibited the highest activity at a relatively low concentration $(10 \mu \mathrm{g} / \mathrm{mL})$. When the concentration was over $10 \mu \mathrm{g} / \mathrm{mL}$, the activities of T $\beta 4$ and DT $\beta 4$ decreased greatly, and disappeared completely at $100 \mu \mathrm{g} / \mathrm{mL}$. In rats, DT $\beta 4$ was found to be more effective at a mid dose $(0.25 \mathrm{mg} / \mathrm{mL})$ than at a high dose $(0.5 \mathrm{mg} / \mathrm{mL})$. In previous preclinical and clinical studies on dermal healing, $\mathrm{T} \beta 4$ has the highest activities at mid doses $(0.2 \mathrm{mg} / \mathrm{mL}$ or $0.3 \mathrm{mg} / \mathrm{mL})$ too. ${ }^{17}$ It is not clear why the lower and higher doses of T $\beta 4$ and DT $\beta 4$ were less effective. It could be related to the bell curve of activity associated with many receptor-mediated biological responses. ${ }^{34}$ Such bioactive molecules can have a narrow effective dose range and differing responses seen at different concentrations are common..$^{35}$

Apart from the activities to promote repair of various tissues, $T \beta 4$ stimulates significant outgrowth from quiescent adult epicardial explants, restoring pluripotency and triggering differentiation of fibroblasts, smooth muscle cells, and endothelial cells. ${ }^{12}$ This suggests its applications 

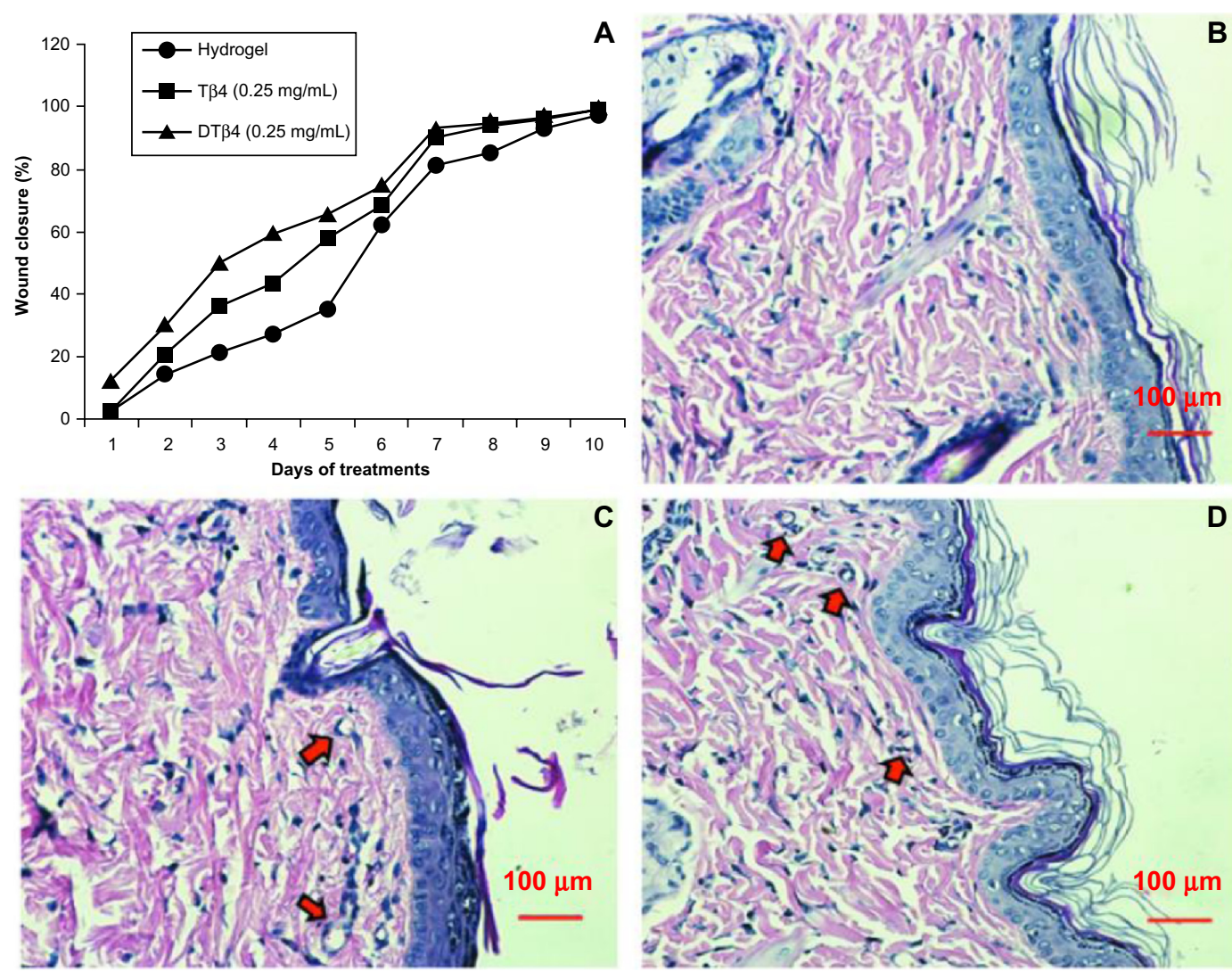

Figure 8 Wound repair evaluation proved either dimeric thymosin beta 4 (DTß4) or thymosin beta 4 (Tß3) increased the healing of punch wounds in rats at $0.25 \mathrm{mg} / \mathrm{mL}$. (A) The rates of $50 \%$ healing in mid-dose DT $\beta 4$-treated $(0.25 \mathrm{mg} / \mathrm{mL})$ rats were approximately 3 days faster than the plain hydrogel or I day faster than T $\beta 4$-treated rats. The healing of the plain hydrogel and T $\beta 4$-treated rats eventually caught up with the mid-dose DT $\beta 4$ treatment at days nine and seven, respectively. Histological sections of (B) plain hydrogel, (C) DT $\beta 4$, and (D) T $\beta 4$ show good re-epithelialization and angiogenesis in subcutaneous tissues. Compared with plain hydrogel, DT $\beta 4$ and T $\beta 4$ resulted in more capillary growth (arrows).

in regenerative medicine. Regenerative medicine is a new field that uses stem cells to regenerate biological tissues and improve tissue functions. ${ }^{36}$ To help the engineered tissue survive and maintain function, some angiogenic molecules such as basic fibroblast growth factor and vascular endothelial growth factor are incorporated into a protein or peptide scaffold. ${ }^{36,37} \mathrm{~T} \beta 4$ or DT $\beta 4$ should be a better alternative for basic fibroblast growth factor or vascular endothelial growth factor considering the multiple activities of T $\beta 4$. In addition, it is vital to establish the side effect and toxicity profile when

Table 2 Wound closure percentage during 10 days treatment with dimeric thymosin beta 4 or thymosin beta 4 hydrogel in normal rats

\begin{tabular}{|c|c|c|c|c|c|}
\hline \multirow[t]{2}{*}{ Cohorts $(n=8)$} & \multicolumn{5}{|l|}{ Days } \\
\hline & $\mathrm{I}$ & 2 & 3 & 4 & 5 \\
\hline Plain hydrogel & $2.3 \pm 1.4$ & $\mid 4.7 \pm 4.1$ & $21.5 \pm 14.4$ & $27.4 \pm 6.8$ & $35.3 \pm 10.8$ \\
\hline $\mathrm{T} \beta 4(0.25 \mathrm{mg} / \mathrm{mL})$ & $2.5 \pm 1.8$ & $20.7 \pm 2.2$ & $36.0 \pm 13.9 *$ & $43.2 \pm 8.2^{* *}$ & $57.8 \pm 10.7 * *$ \\
\hline DT $\beta 4(0.125 \mathrm{mg} / \mathrm{mL})$ & $7.6 \pm 2.1$ & $24.4 \pm 3.8^{*}$ & $40.3 \pm 19.3 *$ & $50.4 \pm 9.5^{* *}$ & $58.3 \pm 11.8^{* *}$ \\
\hline $\mathrm{DT} \beta 4(0.25 \mathrm{mg} / \mathrm{mL})$ & $12.3 \pm 3.6^{*}$ & $30.2 \pm 2.8 * *, \psi$ & $50.0 \pm 18.0^{* *, \psi}$ & $59.2 \pm 11.8^{* *, \psi}$ & $65.5 \pm 13.3^{* *, 4}$ \\
\hline \multirow[t]{3}{*}{ DT $\beta 4(0.5 \mathrm{mg} / \mathrm{mL})$} & $12.6 \pm 1.7^{*}$ & $27.5 \pm 1.6^{*}$ & $46.3 \pm 8.9 * *$ & $52.4 \pm 13.8 * *$ & $60.5 \pm 11.3 * *$ \\
\hline & \multicolumn{5}{|l|}{ Days } \\
\hline & 6 & 7 & 8 & 9 & 10 \\
\hline Plain hydrogel & $62.3 \pm 6.2$ & $81.0 \pm 5.2$ & $85.3 \pm 4.2$ & $93.1 \pm 2.2$ & $97.0 \pm 2.1$ \\
\hline T $\beta 4(0.25 \mathrm{mg} / \mathrm{mL})$ & $68.4 \pm 5.3^{*}$ & $90.0 \pm 6.0^{* *}$ & $93.6 \pm 3.6^{*}$ & $96.1 \pm 1.5$ & $98.3 \pm 2.7$ \\
\hline DT $\beta 4(0.125 \mathrm{mg} / \mathrm{mL})$ & $70.4 \pm 2.6^{*}$ & $90.8 \pm 4.3^{* *}$ & $91.3 \pm 2.7^{*}$ & $93.2 \pm 4.3$ & $96.8 \pm 2.1$ \\
\hline DT $\beta 4(0.25 \mathrm{mg} / \mathrm{mL})$ & $74.6 \pm 7.2^{* *, \psi}$ & $92.8 \pm 3.5^{* *}$ & $94.7 \pm 4.1^{*}$ & $96.4 \pm 2.9$ & $99.0 \pm 1.5$ \\
\hline DT $\beta 4(0.5 \mathrm{mg} / \mathrm{mL})$ & $71.2 \pm 6.4^{*}$ & $88.0 \pm 6.7^{*}$ & $91.3 \pm 3.8^{*}$ & $94.0 \pm 4.2$ & $96.5 \pm 3.3$ \\
\hline
\end{tabular}

Notes: Data are presented as mean \pm standard deviation and were analyzed by Student's $t$-test. $* P<0.05$ versus plain hydrogel; $* * P<0.0$ I versus plain hydrogel; $\psi P<0.05$ versus $T \beta 4$.

Abbreviations: DT $\beta 4$, dimeric thymosin beta 4 ; $T \beta 4$, thymosin beta 4 . 
testing new pharmacological agents. From the clinical trials, monomer T $\beta 4$ was safe and well tolerated when applied topically to the skin or administered intravenously. ${ }^{15,38}$ However, given the previously described metastasis promotion of $\mathrm{T} \beta 4$ on some cancer cells and the upregulation in certain types of malignancy, ${ }^{39}$ it will be essential to establish in early trials that $\mathrm{T} \beta 4$ does not induce cancerous growth. This cannot be ignored either in the studies of DT $\beta 4$ as its ability to promote cell motility is even stronger. Another problem faced by $\mathrm{T} \beta 4$ application in wounding healing is that the response of the patients is inconsistent. Ways to identify $\mathrm{T} \beta 4$ healers and non-healers are required in the future. This should be considered in DT $\beta 4$ applications too. Briefly, any problems occurring in the clinical studies of $\mathrm{T} \beta 4$ should be paid attention to in DT $\beta 4$ studies.

\section{Conclusion}

Taken together, these data indicate that the recombinant DT $\beta 4$ represents a cost-effective means to produce T $\beta 4$ compared with chemical synthesis. The resulting DT $\beta 4$ exhibited a more enhanced activity than the T $\beta 4$ monomer in the promotion of endothelial cell proliferation, migration, capillary formation, and dermal wound repair. It could be of significant medical, economic, and social benefit given the extensive applications of $\mathrm{T} \beta 4$ in the diseases caused by injury. At the same time, the genetic engineering construction of the dimer represents a new method for the production of many small bioactive peptides.

\section{Acknowledgments}

The work in this study was supported by the National Science and Technology Major Project of China (New Drug Innovation Number: 2011ZXJ09104-01B) and National Natural Science Foundation of China (Number: 81272517). The authors thank Dr Ming-Gao Zhao (School of Pharmacy, Fourth Military Medical University, Xian, People's Republic of China) for the wound repair experiment in rats. The authors also thank Mr Christopher Lanza (Santa Clara University, Santa Clara, CA, USA) and Mr Mat Caseres (University of Kansas, Kansas City, KS, USA) for critical reading and English editing of the manuscript.

\section{Disclosure}

Fourth Military Medical University has acquired an invention patent on behalf of Dr Ying-Qi Zhang on the construction and purification of recombinant DT $\beta 4$ presented in this study (ZL 200810232709.9). The other authors disclose no conflicts of interest in this work.

\section{References}

1. Goldstein AL, Slater FD, White A. Preparation, assay, and partial purification of a thymic lymphocytopoietic factor (thymosin). Proc Natl Acad Sci U S A. 1966;56(3):1010-1017.

2. Badamchian M, Damavandy AA, Damavandy H, Wadhwa SD, Katz B, Goldstein AL. Identification and quantification of thymosin beta4 in human saliva and tears. Ann NY Acad Sci. 2007;1112:458-465.

3. Urso E, Le Pera M, Bossio S, Sprovieri T, Qualtieri A. Quantification of thymosin beta(4) in human cerebrospinal fluid using matrix-assisted laser desorption/ionization time-of-flight mass spectrometry. Anal Biochem. 2010;402(1):13-19.

4. Malinda KM, Goldstein AL, Kleinman HK. Thymosin beta 4 stimulates directional migration of human umbilical vein endothelial cells. FASEB J. 1997;11(6):474-481.

5. Grant DS, Kinsella JL, Kibbey MC, et al. Matrigel induces thymosin beta 4 gene in differentiating endothelial cells. J Cell Sci. 1995;108(Pt 12):3685-3694.

6. Koutrafouri V, Leondiadis L, Avgoustakis K, et al. Effect of thymosin peptides on the chick chorioallantoic membrane angiogenesis model. Biochim Biophys Acta. 2001;1568(1):60-66.

7. Qiu P, Wheater MK, Qiu Y, Sosne G. Thymosin beta4 inhibits TNFalpha-induced NF-kappaB activation, IL-8 expression, and the sensitizing effects by its partners PINCH-1 and ILK. FASEB J. 2011;25(6): 1815-1826.

8. Young JD, Lawrence AJ, MacLean AG, et al. Thymosin beta 4 sulfoxide is an anti-inflammatory agent generated by monocytes in the presence of glucocorticoids. Nat Med. 1999;5(12):1424-1427.

9. Ho JH, Tseng KC, Ma WH, Chen KH, Lee OK, Su Y. Thymosin beta-4 upregulates anti-oxidative enzymes and protects human cornea epithelial cells against oxidative damage. $\mathrm{Br} J$ Ophthalmol. 2008;92(7):992-997.

10. Sosne G, Siddiqi A, Kurpakus-Wheater M. Thymosin-beta4 inhibits corneal epithelial cell apoptosis after ethanol exposure in vitro. Invest Ophthalmol Vis Sci. 2004;45(4):1095-1100.

11. Ehrlich HP, Hazard SW 3rd. Thymosin beta4 enhances repair by organizing connective tissue and preventing the appearance of myofibroblasts. Ann NY Acad Sci. 2010;1194:118-124.

12. Smart N, Risebro CA, Melville AA, et al. Thymosin beta4 induces adult epicardial progenitor mobilization and neovascularization. Nature. 2007;445(7124):177-182.

13. Schreml S, Szeimies RM, Prantl L, Landthaler M, Babilas P. Wound healing in the 21 st century. J Am Acad Dermatol. 2010;63(5):866-881.

14. Flamme I, Frölich T, Risau W. Molecular mechanisms of vasculogenesis and embryonic angiogenesis. J Cell Physiol. 1997;173(2):206-210.

15. Crockford D, Turjman N, Allan C, Angel J. Thymosin beta4: structure, function, and biological properties supporting current and future clinical applications. Ann N Y Acad Sci. 2010;1194:179-189.

16. Guarnera G, DeRosa A, Camerini R. The effect of thymosin treatment of venous ulcers. Ann NY Acad Sci. 2010;1194:207-212.

17. Treadwell T, Kleinman HK, Crockford D, Hardy MA, Guarnera GT, Goldstein AL. The regenerative peptide thymosin $\beta 4$ accelerates the rate of dermal healing in preclinical animal models and in patients. Ann NY Acad Sci. 2012;1270:37-44.

18. Bock-Marquette I, Saxena A, White MD, Dimaio JM, Srivastava D. Thymosin beta4 activates integrin-linked kinase and promotes cardiac cell migration, survival and cardiac repair. Nature. 2004;432(7016): 466-472.

19. Rossdeutsch A, Smart N, Riley PR. Thymosin beta4 and Ac-SDKP: tools to mend a broken heart. J Mol Med (Berl). 2008;86(1):29-35.

20. Sosne G, Qiu P, Kurpakus-Wheater M, Matthew H. Thymosin beta4 and corneal wound healing: visions of the future. Ann N Y Acad Sci. 2010;1194:190-198.

21. Morris DC, Chopp M, Zhang L, Lu M, Zhang ZG. Thymosin beta4 improves functional neurological outcome in a rat model of embolic stroke. Neuroscience. 2010;169(2):674-682.

22. Zhang J, Zhang ZG, Morris D, et al. Neurological functional recovery after thymosin beta4 treatment in mice with experimental auto encephalomyelitis. Neuroscience. 2009;164(4):1887-1893. 
23. Che YK, Yang H, Lu F, Pu Q, Li RD, Zhao ZL. Cloning expression in E.coli and biological activity of human thymosin beta(4). Sheng Wu Hua Xue Yu Sheng Wu Wu Li Xue Bao (Shanghai). 2002;34(4):502-505.

24. Li X, Zheng L, Peng F, et al. Recombinant thymosin beta 4 can promote full-thickness cutaneous wound healing. Protein Expr Purif. 2007;56(2):229-236.

25. Bommarius B, Jenssen H, Elliott M, et al. Cost-effective expression and purification of antimicrobial and host defense peptides in Escherichia coli. Peptides. 2010;31(11):1957-1965.

26. Dalle B, Henri A, Rouyer-Fessard P, et al. Dimeric erythropoietin fusion protein with enhanced erythropoietic activity in vitro and in vivo. Blood. 2001;97(12):3776-3782.

27. Li W, Song L, Wu S, et al. Expression, purification and characterization of a novel soluble human thymosin alphal concatemer exhibited a stronger stimulation on mice lymphocytes proliferation and higher anti-tumor activity. Int J Biol Sci. 2011;7(5):618-628.

28. Menke NB, Ward KR, Witten TM, Bonchev DG, Diegelmann RF. Impaired wound healing. Clin Dermatol. 2007;25(1):19-25.

29. Livnah O, Stura EA, Middleton SA, Johnson DL, Jolliffe LK, Wilson IA. Crystallographic evidence for preformed dimers of erythropoietin receptor before ligand activation. Science. 1999;283(5404):987-990.

30. Remy I, Wilson IA, Michnick SW. Erythropoietin receptor activation by a ligand-induced conformation change. Science. 1999;283(5404): 990-993.

31. Sonse G, Qiu P, Goldstein AL, Wheater M. Biological activities of thymosin beta4 defined by active sites in short peptide sequences. FASEB J. 2010;24(7):2144-2151.
32. Fan Y, Gong Y, Ghosh PK, Graham LM, Fox PL. Spatial coordination of actin polymerization and ILK-Akt2 activity during endothelial cell migration. Dev Cell. 2009;16(5):661-674.

33. Bednarek R, Boncela J, Smolarczyk K, Cierniewska-Cieslak A, Wyroba E, Cierniewski CS. Ku80 as a novel receptor for thymosin beta4 that mediates its intracellular activity different from G-actin sequestering. J Biol Chem. 2008;283(3):1534-1544.

34. Occleston NL, O'Kane S, Laverty HG, et al. Discovery and development of avotermin (recombinant human transforming growth factor beta 3): a new class of prophylactic therapeutic for the improvement of scarring. Wound Repair Regen. 2011;19(Suppl 1):s38-s48.

35. Freeman KW, Bowman BR, Zetter BR. Regenerative protein thymosin beta-4 is a novel regulator of purinergic signaling. FASEB $J$. 2011;25(3):907-915.

36. Hosseinkhani H, Hong PD, Yu DS. Self-assembled proteins and peptides for regenerative medicine. Chem Rev. 2013;113(7):4837-4861.

37. Hosseinkhani H, Hosseinkhani M, Khademhosseini A, Kobayashi H, Tabata Y. Enhanced angiogenesis through controlled release of basic fibroblast growth factor from peptide amphiphile for tissue regeneration. Biomaterials. 2006;27(34):5836-5844.

38. Ruff D, Crockford D, Girardi G, Zhang Y. A randomized, placebocontrolled, single and multiple dose study of intravenous thymosin beta4 in healthy volunteers. Ann N Y Acad Sci. 2010;1194:223-229.

39. Chen C, Li M, Yang H, Chai H, Fisher W, Yao Q. Roles of thymosins in cancers and other organ systems. World J Surg. 2005;29(3):264-270. 


\section{Supplementary materials \\ Materials and methods}

Expression of dimeric T $\beta 4$ (DT $\beta 4$ ) and large-scale cultivation of engineered bacteria

The pET22b-DT $\beta 4$ plasmid was transformed into Escherichia coli BL21 (DE3; Promega Corporation, Fitchburg, WI, USA) using the calcium chloride method. Five BL21 clones successfully transformed by pET22b-DT $\beta 4$ were picked for recombinant DT $\beta 4$ expression. The initial expression was performed in lysogeny broth supplemented with ampicillin $(100 \mathrm{mg} / \mathrm{L})$ at $200 \mathrm{~mL}$ scale $\left(37^{\circ} \mathrm{C}, 200 \mathrm{rpm}\right)$. A final concentration of $0.01 \mathrm{mmol} / \mathrm{L}$ isopropyl $\beta$-D-1-thiogalactopyranoside (Sigma-Aldrich, St Louis MO, USA) was used for induction when the optical density at $600 \mathrm{~nm}$ reached $0.4-0.5$. After 5 hours induction, $10 \mu \mathrm{g}$ bacteria pastes were boiled and separated by $15 \%$ sodium dodecyl sulfate polyacrylamide gel electrophoresis. The expression of the target protein was evaluated by gel documentation system (GDS-8000; UVP, Inc, Upland, CA, USA). The clone which had the highest DT $\beta 4$ expression was used for large-scale cultivation.

Large-scale cultivation was performed using a $10 \mathrm{~L}$ fermenter (CT5-2; B. Braun Biotech International GmbH, Melsungen, Germany) with $8.5 \mathrm{~L}$ optimized 2YT medium at $500 \mathrm{rpm}$, air gassing (dissolved oxygen $>30 \%$ ), and $\mathrm{pH} 7.0$. An initial overnight pre-culture of the selected clone was $5 \mathrm{~mL}$. After two successional inoculations, the pre-culture was amplified to $400 \mathrm{~mL}$ and optical density at $600 \mathrm{~nm}$ was $>2$. The amplified pre-culture was then inoculated into the fermenter. After 6 hours growth, the optical density at $600 \mathrm{~nm}$ reached 6 and induction was initiated by $0.2 \mathrm{mmol} / \mathrm{L}$ isopropyl $\beta$-D-1-thiogalactopyranoside. The cultivation was sampled every hour and the expression of DT $\beta 4$ was examined by sodium dodecyl sulfate polyacrylamide gel electrophoresis. All bacteria were harvested 5 hours after induction by centrifugation.

\section{Purification of DT $\beta 4$}

A $10 \%$ (weight/volume) bacteria suspension in $50 \mathrm{mmol} / \mathrm{L}$ tris(hydroxymethyl)aminomethane-hydrogen chloride with $100 \mathrm{mmol} / \mathrm{L}$ sodium chloride and $5 \mathrm{mmol} / \mathrm{L}$ ethylenediaminetetraacetic acid (buffer A, $\mathrm{pH}$ 8.0) was prepared for the purification of DT $\beta 4$. The cells were lysed by sonification using an ultrasonic processor (JY92-2D; Xinzhi Biotech Co., Ningbo, People's Republic of China). The cell debris was removed by centrifugation $(12,000 \mathrm{rpm}, 20$ minutes, $4^{\circ} \mathrm{C}$ ). Grinded ammonium sulfate was added to the cellfree extract to $50 \%$ saturation. After precipitation at $4{ }^{\circ} \mathrm{C}$ overnight, the supernatant was collected and loaded to a hydrophobic interaction chromatography column (Phenyl Sepharose ${ }^{\mathrm{TM}} 6$ Fast Flow; GE Healthcare Bio-Sciences AB, Uppsala, Sweden) using a protein purification system (AKTApurifier 10 plus; GE Healthcare). The column was equilibrated by buffer A supplemented with $50 \%$ ammonium sulfate. The target protein was eluted with a linear gradient of ammonium sulfate from $50 \%$ to $0 \%$. Fraction containing target protein was collected and dialyzed into $20 \mathrm{mmol} / \mathrm{L}$ phosphate-buffered saline ( $\mathrm{pH}$ 7.4) or normal saline according for later use.

\section{Bioactivities of DT $\beta 4$ in vitro and in vivo The effect of DT $\beta 4$ on the migration of human umbilical vein endothelial cells (HUVEC)}

The effect of DT $\beta 4$ to promote the migration of HUVEC was tested by trans-well assay and scratch assay. Each assay was repeated at least three times. For trans-well assay, HUVEC $\left(3 \times 10^{4} /\right.$ well $)$ were plated evenly in upper chambers of the Transwell ${ }^{\circledR}$ plates (Corning Incorporated, Tewksbury, MA, USA) and incubated at $37^{\circ} \mathrm{C}$ for 4 hours. DT $\beta 4$ or T $\beta 4$ was applied to the bottom chambers at $1 \mu \mathrm{g} / \mathrm{mL}$ and $10 \mu \mathrm{g} / \mathrm{mL}$. Another 4 hours later, the filter of each well was fixed with 4\% paraformaldehyde and stained with Invitrogen ${ }^{\circledR} 4$, 6-diamidino-2-phenylindole (Life Technologies, Carlsbad, CA, USA). The cells on each filter were counted on a fluorescence microscope (Axioskop 2 plus; Carl Zeiss AG, Oberkochen, Germany).

For the scratch assay, HUVEC were grown to a confluent monolayer in $60 \mathrm{~mm}$ dishes (Corning). Similar size straight lines were created by scraping the cell monolayer with a pipette tip in all dishes. The cells were washed with phosphate-buffered saline and then incubated with serumfree medium supplemented with $1 \mu \mathrm{g} / \mathrm{mL}$ and $10 \mu \mathrm{g} / \mathrm{mL}$ of DT $\beta 4$ or T $\beta 4$ for 12 hours. The images of each sample were collected on a phase-contrast microscope (CX31; Olympus Corporation, Tokyo, Japan) every 2 hours, matching the reference point every time. The scratch closure was measured by quantifying the total distance that the cells moved from the edge of the scratch toward the center of the scratch using ImageJ (National Institutes of Health, Bethesda, MD, USA).

\section{The effect of DT $\beta 4$ on angiogenesis}

The effect of DT $\beta 4$ to stimulate angiogenesis was evaluated by endothelial tube formation assay as follows. The wells of a 96-well plate were coated with Matrigel ${ }^{\mathrm{TM}}\left(\mathrm{Cultrex}^{\circledR}\right.$ BME; BD Biosciences, San Jose, CA, USA) according to the manufacturer. HUVEC were plated into the coated 
wells $\left(2 \times 10^{4}\right.$ cells/well $)$ after the Matrigel jellied. DT $\beta 4$ or $\mathrm{T} \beta 4$ were applied to the cells at $1 \mu \mathrm{g} / \mathrm{mL}$ and $10 \mu \mathrm{g} / \mathrm{mL}$ in triplicate. Eight hours later, the images were collected using a phase-contrast microscope (CX31). The capillary-like structures featured as a central lumen surrounded by endothelial cells were counted in each view using Image J.

\section{The effects of DT $\beta 4$ on the wound healing in rats}

DT $\beta 4$ hydrogel were prepared at three concentrations: $0.5 \mathrm{mg} / \mathrm{mL}, 0.25 \mathrm{mg} / \mathrm{mL}$, and $0.125 \mathrm{mg} / \mathrm{mL}$. T $\beta 4$ hydrogel was prepared at $0.25 \mathrm{mg} / \mathrm{mL}$ and used as the control. Two full-thickness $8 \mathrm{~mm}$ punch wounds were made on the dorsal surface of each rat as previously described. ${ }^{1}$ Eight rats (four females and four males) were used for each data point. The hydrogels were applied topically using cotton Q-tip swabs two times every day $(0.5 \mathrm{~mL} /$ wound/time $)$ for 10 days. The rats were bandaged with petroleum jelly-impregnated gauze. Control animals received plain hydrogel alone. The general condition, behavior, and wound repair of all animals were checked daily. For wound repair evaluation, a transparent acetate sheet (Sigma) was placed on the wound, its perimeter was traced and then sheared along the wound tracing, and the sheared part was weighed. Data are expressed as the percentage of wound closure (100 - weight of sheared acetate/weight of sheared acetate of the initial day $\times 100$ ). Wound tissues were collected after euthanasia at day eleven and fixed in 10\% buffered formalin (Sigma). The tissues were then sectioned from the middle of the wounds, stained with hematoxylin-eosin, and histopathologic interpretation of each section was performed by a pathologist blinded to treatment. Meanwhile, all animals underwent autopsy for examination.

\section{Reference}

1. Malinda KM, Sidhu GS, Mani H, et al. Thymosin beta4 accelerates wound healing. J Invest Dermatol. 1999;113(3):364-368.
Drug Design, Development and Therapy

\section{Publish your work in this journal}

Drug Design, Development and Therapy is an international, peerreviewed open-access journal that spans the spectrum of drug design and development through to clinical applications. Clinical outcomes, patient safety, and programs for the development and effective, safe, and sustained use of medicines are a feature of the journal, which

\section{Dovepress}

has also been accepted for indexing on PubMed Central. The manuscript management system is completely online and includes a very quick and fair peer-review system, which is all easy to use. Visit http://www.dovepress.com/testimonials.php to read real quotes from published authors. 